\title{
Thymol and carvacrol: biotransformation and antifungal activity against the plant pathogenic fungi Colletotrichum acutatum and Botryodiplodia theobromae
}

\author{
Manuel A. Numpaque ${ }^{1}$, Luis A. Oviedo ${ }^{1}$, Jesús H. Gil ${ }^{1,2}$, Carlos M. García ${ }^{1}$ \& Diego L. Durango ${ }^{1}$ \\ ${ }^{1}$ Grupo de Química de los Productos Naturales y los Alimentos, Facultad de Ciencias, Escuela de Química, Universidad \\ Nacional de Colombia, AA 3840, Antioquia, Medellín, Colombia; ${ }^{2}$ Facultad de Ciencias Agropecuarias, Departamento de \\ Ingeniería Agrícola y Alimentos, Universidad Nacional de Colombia, AA 3840, Antioquia, Medellín, Colombia
}

Author for correspondence: Diego L. Durango, e-mail: dldurango@unal.edu.co

\begin{abstract}
Fungal growth in fruits may cause spoilage and result in a reduction of their quality and quantity. The aim of the current study was to investigate the antifungal activity and the metabolism of thymol and carvacrol by Colletotrichum acutatum and Botryodiplodia theobromae. The results showed that both compounds provided relatively good control against these plant pathogenic fungi. Mycelial growth of $C$. acutatum and B. theobromae was inhibited at $50 \mu \mathrm{g} / \mathrm{mL}$ and above. At $150 \mu \mathrm{g} / \mathrm{mL}$, thymol and carvacrol inhibited the radial growth of fungi completely and this effect remained for $240 \mathrm{~h}$. Furthermore, thymol and carvacrol were metabolized by the plant pathogenic fungi in low proportion to several compounds, including thymoquinone, thymohydroquinone, thymyl- and carvacryl acetate, thymyland carvacryl methyl ether. The transformations affect the structural requirements of thymol and carvacrol related to their antimicrobial activity and mode of action. The relatively high antifungal activity of thymol and carvacrol against C. acutatum and B. theobromae and the low levels of microbial transformation indicate that both compounds could be an alternative to traditional chemical fungicides for control of pre- and postharvest phytopathogenic fungi on fruits or vegetables.
\end{abstract}

Key words: Alternative control, arylpropanoids, fungal detoxification, metabolic pathways, thymoquinone.

\section{RESUMEN}

Timol y carvacrol: biotransformación y actividad antifúngica contra los hongos fitopatogénicos Colletotrichum acutatum y Botryodiplodia theobromae

El crecimiento de los hongos en frutas puede causar el deterioro de los alimentos y resultar en una reducción de la calidad y la productividad. El objetivo del presente estudio fue investigar la actividad antifúngica, y el metabolismo de timol y carvacrol por Colletotrichum acutatum y Botryodiplodia theobromae. Los resultados muestran que ambos compuestos despliegan un relativo buen control contra los hongos fitopatogénicos; el crecimiento micelial de C. acutatum y B. theobromae se inhibió a concentraciones de 50 $\mu \mathrm{g} / \mathrm{mL}$ y mayores. A $150 \mu \mathrm{g} / \mathrm{mL}$, timol y carvacrol inhibieron el crecimiento radial de los hongos completamente y este efecto permaneció durante $240 \mathrm{~h}$. Además, los hongos fitopatogénicos metabolizaron timol y carvacrol a varios compuestos en una baja proporción, incluyendo timoquinona, timohidroquinona, timil- y carvacril acetato, timil- y carvacril metil eter, entre otros. Las transformaciones afectan los requerimientos estructurales del timol y carvacrol relacionados con su actividad antimicrobiana y modo de acción. La actividad antifúngica relativamente alta de timol y carvacrol contra $C$. acutatum and $B$. theobromae y los niveles de transformación microbiana bajos, indican que ambos compuestos pueden ser una alternativa a los fungicidas químicos tradicionales para el control de los hongos fitopatogénicos en pre- y poscosecha de frutas y vegetales.

Palabras-clave: Arilpropanóides, control alternativo, desintoxicación fúngica, rutas metabólicas, timoquinona.

\section{INTRODUCTION}

Stem-end rot (Botryodiplodia theobromae) and anthracnose (Colletotrichum acutatum) are two serious diseases that contribute significantly to harvest and postharvest loss of tamarillo, avocado, mango, papaya, and citrus in Colombia (Afanador-Kafuri et al., 2003; Martínez et al., 2009). The use of synthetic chemicals as fungicides is the primary method of control of postharvest fungal decay caused by both diseases. However, the rapid development of tolerance to commercial fungicides by $C$. acutatum and
B. theobromae has led to an increase in the quantities of these compounds that have to be used. Consequently, the presence of fungicide residues on the fruits decreases their quality and can prevent their export to some foreign markets (Tripathi \& Dubey, 2004). Furthermore, the use of synthetic chemicals to control pre- and postharvest deterioration of food commodities is restricted, due to their possible carcinogenicity, teratogenicity, acute toxicity, environmental pollution and side effects on human beings (Tripathi \& Shukla, 2007). Therefore, the fruit industry urgently demands alternative pre- and postharvest treatments that are 
free of synthetic fungicides and acceptable to consumers. Given these facts, the use of essential oils and some of their constituents can be a very attractive method for pre- and postharvest disease control of fruits, due to their relative safety and wide acceptance by consumers (Ormancey et al., 2001).

Carvacrol (5-isopropyl-2-methylphenol; - "C") and thymol (2-isopropyl-5-methylphenol; - "T") are the main components of the essential oils of some Laminaceae members like oregano, thyme, and savory. They are produced by these plant species as a chemical defense mechanism against phytopathogenic microorganisms (Vázquez et al., 2001). Accordingly, the potent antimicrobial and fungitoxic properties of $(\mathrm{C})$ and $(\mathrm{T})$ against various plant pathogens have been previously documented (Sokovic et al., 2002; Falcone et al., 2005). It has been found that these agents cause alterations in the hyphal morphology and hyphal aggregates, resulting in reduced hyphal diameters and lyses of hyphal wall, as these interact with the cell membrane of the pathogen (Soylu et al., 2007). In addition, chemical modification of these phenolic compounds to various ether and ester derivatives has been reported to result in change in biological activity (Mathela et al., 2010).

Despite their antimicrobial characteristics, Chamberlain and Dagley (1968) found a Pseudomonas strain able to degrade $(\mathrm{T})$ completely and $(\mathrm{C})$ partially. The authors proposed a metabolic pathway for $(\mathrm{T})$ that involves meta-ring opening of a trihydric phenol, 3-hydroxythymo-1,4-quinol to 3,7-di-methyl-2,4,6-trioxo-octanoate. Hydrolysis of the latter, catalyzed by $\beta$-ketolase, yields acetate, 2 -ketobutyrate and isobutyrate. Thus, biotransformation experiments provide information on the detoxification mechanism used by phytopathogenic microorganisms and give an indication of the structural modifications that may be necessary if substrates of this type are to be further developed as selective fungal control agents (Daoubi et al., 2005). The aim of the present study was to evaluate the antifungal properties against $C$. acutatum and B. theobromae of $(\mathrm{T})$ and $(\mathrm{C})$, along with their metabolism.

\section{MATERIALS AND METHODS}

\section{Biological and chemical materials \\ $C$. acutatum and $B$. theobromae were isolated from} infected tamarillo (Solanum betacea) and avocado (Persea americana) fruits, respectively. Fungi were characterized and kindly provided by the Laboratory of Phytopathology (Universidad Nacional de Colombia-Medellín). Pure cultures were maintained on potato dextrose agar (PDA) at $24^{\circ} \mathrm{C}$, and freshly subcultured before using in the transformation experiment. The substrates for biotransformation, (T) and $(\mathrm{C})$, were purchased from Abaquim Ltda. (Medellín, Colombia) and Merck KGaA (Darmstadt, Germany), respectively. Thymoquinone was obtained from SigmaAldrich Co. (St. Louis, MO, USA). Thymohydroquinone was prepared by reduction of thymoquinone, as described by El-Dakhakhny (1963). Methylated and acetylated derivatives of $(\mathrm{T})$ and $(\mathrm{C})$ were obtained according to
Mathela et al. (2010), and Smith \& March (2007). The purified synthetic compounds were analyzed by ${ }^{1} \mathrm{H}$ - and ${ }^{13} \mathrm{C}$ Nuclear magnetic resonance (NMR) spectroscopy and gas chromatography-mass spectrometry (GC-MS) to confirm their identity and purity.

\section{Antifungal bioassay}

In order to investigate the antifungal activity of (T) and (C), against the microorganisms, the poisoned food technique described by Grover and Moore (1962) with slight modifications, was used. In poisoned food technique, both fungi were inoculated on Potato dextrose agar (PDA) plates and incubated at $25^{\circ} \mathrm{C}$ for $48 \mathrm{~h}$ to obtain young, actively growing colonies. A total of $30 \mu \mathrm{L}$ of ethanolic solutions of $(\mathrm{T})$ and $(\mathrm{C})$ at concentrations of $0.0250,0.0375,0.0500$, $0.0625,0.0750$ and $0.100 \mathrm{mg} / \mu \mathrm{L}$ were taken and mixed with $15 \mathrm{~mL}$ of cooled molten PDA medium (final concentrations $50,75,100,125,150$ and $200 \mu \mathrm{g} / \mathrm{mL}$ ), and allowed to solidify at room temperature for thirty minutes. Concentration at 125 $\mu \mathrm{g} / \mathrm{mL}$ of (T) and (C) was not evaluated for B. theobromae. Subsequently, a mycelial disc (5 $\mathrm{mm}$ in diameter) of $C$. acutatum or $B$. theobromae, cut with a sterile cork borer from the periphery of $48 \mathrm{~h}$ old cultures, was aseptically inoculated onto the agar plates containing $(\mathrm{T})$ or $(\mathrm{C})$. Petri dishes with PDA plus ethanol $(2 \mu \mathrm{L} / \mathrm{mL})$ were used as a control. The plates were incubated at room temperature and the diameter of the mycelial growth was measured every 24 hours. Incubation was ceased when the mycelial mass of control Petri dishes had almost filled it (ca. 240 and 144 hours for C. acutatum and B. theobromae, respectively). All concentrations were tested in triplicate. The relative growth inhibition of the treatment compared to the control was calculated as percentage, using the following formula:

Inhibition $(\%)=\{1-[$ radial growth of treatment $(\mathrm{mm}) /$ radial growth of control $(\mathrm{mm})]\} \times 100$

\section{Pre-culture of $\boldsymbol{C}$. acutatum and $\boldsymbol{B}$. theobromae}

Fungi were transferred into 1.0 L Erlenmeyer flasks containing $500 \mathrm{~mL}$ of Czapeck-Dox liquid medium (Solution A: Glucose 5\%, yeast extract $0.1 \%$; Solution B: $\mathrm{K}_{2} \mathrm{HPO}_{4} 0.5 \%$, $\mathrm{NaNO}_{3} 0.2 \%, \mathrm{MgSO}_{4} 7 \mathrm{H}_{2} \mathrm{O} 0.05 \%, \mathrm{FeSO}_{4} 7 \mathrm{H}_{2} \mathrm{O} 0.001 \%$ ). Erlenmeyer flasks were agitated in a reciprocating shaker (Centricol series 0239) at $120 \mathrm{rpm}$ and room temperature for 8 days. Mycelia were harvested by filtration, washed with sterile $\mathrm{H}_{2} \mathrm{O}$ and immediately employed in the biotransformation and time course experiments.

\section{Biotransformation, isolation and identification of metabolic products}

Mycelia of $C$. acutatum and B. theobromae were transplanted into four 1.0 L Erlenmeyer flasks containing $500 \mathrm{~mL}$ of sterilized Czapeck-Dox culture medium and substrate (at $80 \mu \mathrm{g} / \mathrm{mL}$ ). Flasks were incubated on a reciprocating shaker $(120 \mathrm{rpm})$ at room temperature for 14 days. A substrate-free control was included in all 
experiments. After incubation, culture medium and mycelia were separated by filtration. Mycelia were discarded and culture medium was saturated with $\mathrm{NaCl}$ and extracted with ethyl acetate $(E t O A c, 3 \times 2.0 \mathrm{~L})$. Afterwards, the medium was acidified to $\mathrm{pH} 2$ with $1 \mathrm{M} \mathrm{HCl}$, and extracted again with $\mathrm{CH}_{2} \mathrm{Cl}_{2}(2 \times 2.0 \mathrm{~L})$. Both organic extracts were mixed, dried over anhydrous $\mathrm{Na}_{2} \mathrm{SO}_{4}$ and concentrated in vacuum. Some metabolites were partially purified by column chromatography (CC), passing the extract through a silica gel 60 (mobile phase: mixtures of $n$-hexane: EtOAc) column, and then through a Sephadex LH-20 column (mobile phase: mixture of $n$-hexane: $\mathrm{CH}_{2} \mathrm{Cl}_{2}$ : methanol, 2:1:1 v/v). The structures of the products were determined by mass spectrometry (MS), ${ }^{1} \mathrm{H}$ and ${ }^{13} \mathrm{C}$ NMR analysis, and comparison with the NIST 2002 computerized mass spectral library and authentic standards (Table 1).

\section{Time-course experiment}

Pre-cultured $C$. acutatum or B. theobromae was transferred into fourteen $500 \mathrm{~mL}$ Erlenmeyer flasks, each containing $125 \mathrm{~mL}$ of Czapeck-Dox liquid medium and substrate $(\mathrm{T})$ or $(\mathrm{C})$, and stirred for 14 days under the same conditions as described for preculture. Daily, the content of one flask was removed for each of 14 days, saturated with $\mathrm{NaCl}$, and extracted with EtOAc $(3 \times 150$ $\mathrm{mL})$. The extracts obtained after solvent evaporation were analyzed by thin layer chromatography (TLC) and GC-MS. The ratios between the substrate and metabolic products were determined on the basis of GC peak areas. Control cultures in which the microorganism was grown under identical conditions, but without substrate, were carried out.

\section{Analytical methods}

TLC was performed on precoated plates ( $\mathrm{Si} 60$ $\mathrm{F}_{254}, 0.25 \mathrm{~mm}$, Merk) using mixtures of $n$-hexane:EtOAc as mobile phase. Column chromatography (CC) used silica gel 60 (0.040-0.063 mm; Merck) and Sephadex LH-20 (Sigma-Aldrich Co., St. Louis, MO, USA). Gas chromatography (GC) was performed on a HewlettPackard 6890 (Agilent Technologies) gas chromatograph equipped with a HP 5973 MSD (Mass selective detectorQuadrupole type). A HP-5 column (30 m x $0.25 \mathrm{~mm}$ i.d.; coating thickness $0.25 \mu \mathrm{m}$ ) was used. Chromatographic conditions were as follows: column temperature, 50$250^{\circ} \mathrm{C}$ at $10^{\circ} \mathrm{C} / \mathrm{min}$ and keep for five minutes; injector temperature, $150^{\circ} \mathrm{C}$; detector temperature, $280^{\circ} \mathrm{C}$; carrier gas, $\mathrm{N}_{2}$ at $1 \mathrm{~mL} / \mathrm{min}$. Relative composition of the individual constituents was determined from the average area of the peaks. Electron ionization mass spectrometry (EI-MS) measurements were obtained using GC-MS. Chromatographic conditions were the same as described earlier. Substances were identified by comparison of their mass spectra with those of reference substances and by comparison with the NIST 2002 Mass Spectral Library. NMR spectra were measured on a Bruker AMX 300
NMR spectrometer $\left({ }^{1} \mathrm{H}\right.$ NMR, $300.12 \mathrm{MHz} ;{ }^{13} \mathrm{C}$ NMR, $75.42 \mathrm{MHz}$ ). Chemical shifts, $\delta$, are expressed in ppm units downfield from TMS and coupling constant $J$ is in Hertz (Hz).

\section{RESULTS AND DISCUSSION}

\section{Antifungal activity}

The inhibitory effects of (T) and (C) against $C$. acutatum and B. theobromae are shown in Figures 1 and 2. As can be seen, mycelial growth of these fungi was dependent on the concentration of $(\mathrm{C})$ and $(\mathrm{T})$ in the culture medium. At $150 \mu \mathrm{g} / \mathrm{mL}$ and above, (C) and (T) inhibited the radial growth of $C$. acutatum completely and this effect remained during the $240 \mathrm{~h}$ duration of the experiment (Figure 1). Furthermore, fungal colony development initiated only 48 and 96 hours after inoculation when C. acutatum was treated with (C) and (T) at $100 \mu \mathrm{g} / \mathrm{mL}$, respectively. In addition, inhibition percentages of C. acutatum at $75 \mu \mathrm{g} / \mathrm{mL}$ ranged from 25 $30 \%$ for (C) and $50-60 \%$ for (T). This shows a slightly higher antifungal activity of $(\mathrm{T})$ in comparison to (C) against $C$. acutatum. In the case of $B$. theobromae, its growth was completely inhibited when a concentration of 150 and $200 \mu \mathrm{g} / \mathrm{mL}$ of (C) or (T) was used. In general, results revealed that $(\mathrm{C})$ and $(\mathrm{T})$ exhibited a relatively high antifungal action toward C. acutatum and B. theobromae. Some of these results are in agreement with those obtained earlier by Alzate et al. (2009). The antifungal activity of (T) and (C) against other plant pathogenic fungi has also been investigated (Tsao \& Zhou, 2000; Holley \& Patel, 2005). In particular, (T) and (C) showed a very strong antifungal activity against Phytophthora cactorum and Cryphonectria parasitica at $28 \times 10^{-3} \mathrm{mg} / \mathrm{mL}$ air concentration (Kim et al., 2008), and a complete growth inhibition of Alternaria arborescens and Rhizopus stolonifer (Plotto et al., 2003). Consequently, the potent antimicrobial properties of (T) and (C) against spoilage bacteria and food borne pathogens have been also reported in the literature (Valero et al., 2006).

The mode of action for (C) and (T) is uncertain; however, activity may be linked to the hydrophobicity and consequently, the ability of both compounds to pass through the fungal cell membrane (Knobloch et al., 1988), which further affects $\mathrm{pH}$ homeostasis and equilibrium of inorganic ions (Ultee et al., 2000; Cristani et al., 2007) disturbing the cell structures. Furthermore, the involvement of the hydroxyl group in the formation of hydrogen bonds and the acidity of these phenolic compounds may be another important factor involved in the bioactivity. Ultee et al. (2000) additionally hypothesized that (C) acts as a proton exchanger, thereby reducing the $\mathrm{pH}$ gradient across the cytoplasmic membrane. This leads to the collapse of the proton motive force and depletion of the ATP pool, causing cell death. Moreover, it seems possible that both compounds may interfere with cell 
M.A. Numpaque et al.

TABLE 1 - GC retention time $(R t)$ and EI mass spectral properties and identification of products detected in incubation of C. acutatum and B. theobromae with (T) and (C)

\begin{tabular}{|c|c|c|c|}
\hline $\begin{array}{l}\text { Compound } \\
\text { No. }\end{array}$ & $\begin{array}{c}R t \\
(\min )\end{array}$ & $m / z$ of fragment ions [\% relative intensity] & Identification \\
\hline $\begin{array}{l}(C C 1),(T C 2) \\
(C B 2),(T B 2)\end{array}$ & 18.94 & $\begin{array}{l}166\left(\mathrm{M}^{+}\right)[47], 152[14], 151\left(\mathrm{M}^{+}-\mathrm{CH}_{3}\right)[100] \\
137,123\left(\mathrm{M}^{+}-\mathrm{C}_{3} \mathrm{H}_{7}\right)[10], 95[10], 83[10] \\
77,71,69,57,55,43\left(\mathrm{C}_{3} \mathrm{H}_{7}^{+}\right)[14], 41[10]\end{array}$ & Thymohydroquinone ${ }^{*}$ \\
\hline$(C C 2),(C B 4)$ & 16.96 & $\begin{array}{l}166\left(\mathrm{M}^{+}\right)[24], 151\left(\mathrm{M}^{+}-\mathrm{CH}_{3}\right)[41], 138[21] \\
107\left(\mathrm{M}^{+}-\mathrm{C}_{3} \mathrm{H}_{6} \mathrm{O}-\mathrm{H}\right) \quad[71], 83,77,57,43 \\
\left(\mathrm{C}_{3} \mathrm{H}_{7}^{+}\right)[100] .\end{array}$ & 5-(1-Hydroxy-1-methyl-ethyl)-2-methyl-phenol \\
\hline$(C C 3)$ & 19.34 & $\begin{array}{l}164\left(\mathrm{M}^{+}\right)[100], 149\left(\mathrm{M}^{+}-\mathrm{CH}_{3}\right)[30], 147 \\
\left(\mathrm{M}^{+}-\mathrm{OH}\right)[12], 137[11], 121\left(\mathrm{M}^{+}-\mathrm{C}_{3} \mathrm{H}_{7}\right) \\
{[26], 107,91\left(\mathrm{C}_{7} \mathrm{H}_{7}^{+}\right)[19], 77\left(\mathrm{C}_{5} \mathrm{H}_{5}^{+}\right)[11]} \\
57,55,39 .\end{array}$ & 2-Isopropenyl-5-methyl-benzene-1,4-diol $l^{\ddagger}$ \\
\hline$(C C 4)$ & 17.50 & $\begin{array}{l}164\left(\mathrm{M}^{+}\right)[100], 149\left(\mathrm{M}^{+}-\mathrm{CH}_{3}\right)[40], 121 \\
\left(\mathrm{M}^{+}-\mathrm{C}_{3} \mathrm{H}_{7}\right)[27], 103,91\left(\mathrm{C}_{7} \mathrm{H}_{7}^{+}\right)[16], 77 \\
\left(\mathrm{C}_{5} \mathrm{H}_{5}^{+}\right)[11], 43 .\end{array}$ & Carvacryl methyl ether ${ }^{\dagger, *}$ \\
\hline$(C C 5),(C B 5)$ & 14.05 & $\begin{array}{l}164\left(\mathrm{M}^{+}\right)[63], 149\left(\mathrm{M}{ }^{+}-\mathrm{CH}_{3}\right)[70], 136 \\
\left(\mathrm{M}^{+}-\mathrm{CO}\right)[40], 135\left(\mathrm{M}^{+}-\mathrm{HCO}\right)[51], 121 \\
\left(\mathrm{M}^{+}-\mathrm{C}_{3} \mathrm{H}_{7}\right)[81], 108\left(\mathrm{M}^{+}-\mathrm{CO}-\mathrm{C}_{2} \mathrm{H}_{4}\right)[29], \\
107[25], 93[100], 91\left(\mathrm{C}_{7} \mathrm{H}_{7}^{+}\right)[61], 79[35], \\
77\left(\mathrm{C}_{5} \mathrm{H}_{5}^{+}\right)[47], 68[45], 39[85] .\end{array}$ & Thymoquinone $e^{\dagger, *}$ \\
\hline$(C C 6),(C B 7)$ & 13.28 & $\begin{array}{l}192\left(\mathrm{M}^{+}\right)[7], 150\left(\mathrm{M}^{+}-\mathrm{H}_{2} \mathrm{C}_{2} \mathrm{O}\right)[58], 135 \\
\left(\mathrm{M}^{+}-\mathrm{H}_{2} \mathrm{C}_{2} \mathrm{O}-\mathrm{CH}_{3}\right)[100], 91\left(\mathrm{C}_{7} \mathrm{H}_{7}^{+}\right)[14], 83 \\
77\left(\mathrm{C}_{5} \mathrm{H}_{5}^{+}\right), 44 .\end{array}$ & Carvacryl acetate ${ }^{\dagger}, *$ \\
\hline$(T C 1),(T B 1)$ & 19.36 & $\begin{array}{l}166(\mathrm{M})^{+}[40], 151 \quad\left(\mathrm{M}^{+}-\mathrm{CH}_{3}\right)[100], 133 \\
\left(\mathrm{M}^{+}-\mathrm{H}_{2} \mathrm{O}-\mathrm{CH}_{3}\right)[9], 121\left(\mathrm{M}^{+}-\mathrm{H}_{2} \mathrm{CO}-\mathrm{CH}_{3}\right) \\
{[20], 107\left(\mathrm{M}-\mathrm{H}_{2} \mathrm{CO}-\mathrm{C}_{2} \mathrm{H}_{4}-\mathrm{H}\right)[8], 105[8]} \\
103[8], 95[10], 91[10], 77\left(\mathrm{C}_{6} \mathrm{H}_{5}^{+}\right)[18] .\end{array}$ & 2-(1-hydroxypropan-2-yl)-5-methylphenot \\
\hline$(T C 3)$ & 18.33 & $\begin{array}{l}164(\mathrm{M})^{+}[41], 149\left(\mathrm{M}^{+}-\mathrm{CH}_{3}\right)[100], 135[29], \\
121\left(\mathrm{M}^{+}-\mathrm{C}_{3} \mathrm{H}_{7}\right)[29], 105[38], 103[24], 91 \\
\left(\mathrm{C}_{7} \mathrm{H}_{7}^{+}\right)[46], 77\left(\mathrm{C}_{6} \mathrm{H}_{5}^{+}\right)[36], 43\left(\mathrm{C}_{3} \mathrm{H}_{7}^{+}\right)^{[81] .}\end{array}$ & Thymyl methyl ether ${ }^{*}$ \\
\hline$(C B 1)$ & 19.25 & $\begin{array}{l}166\left(\mathrm{M}^{+}\right)[28], 135\left(\mathrm{M}^{+}-\mathrm{H}_{2} \mathrm{CO}-\mathrm{H}\right)[100], 115 \\
{[11], 105\left(\mathrm{M}^{+}-\mathrm{H}_{2} \mathrm{O}-\mathrm{C}_{2} \mathrm{H}_{4}-\mathrm{CH}_{3}\right)[32], 91} \\
\left(\mathrm{C}_{7} \mathrm{H}_{7}^{+}\right)[22], 79[8], 77\left(\mathrm{C}_{6} \mathrm{H}_{5}^{+}\right)[10] .\end{array}$ & 5-(2-hydroxy-1-methyl-ethyl)-2-methyl-phenol ${ }^{\ddagger}$ \\
\hline$(C B 3)$ & 18.35 & $\begin{array}{l}166\left(\mathrm{M}^{+}\right)[29], 148\left(\mathrm{M}^{+}-\mathrm{H}_{2} \mathrm{O}\right)[56], 133 \\
\left(\mathrm{M}^{+}-\mathrm{H}_{2} \mathrm{O}-\mathrm{CH}_{3}\right)[21], 105[100], 91\left(\mathrm{C}_{7} \mathrm{H}_{7}\right)^{+} \\
{[19], 83,77\left(\mathrm{C}_{6} \mathrm{H}_{5}^{+}\right)[25], 57[14], 43\left(\mathrm{C}_{3} \mathrm{H}_{7}^{+}\right)} \\
{[15] .}\end{array}$ & 2-hydroxymethyl-5-isopropyl-phenol ${ }^{\ddagger}$ \\
\hline$(C B 6)$ & 14.15 & $\begin{array}{l}148\left(\mathrm{M}^{+}\right)[100], 133\left(\mathrm{M}^{+}-\mathrm{CH}_{3}\right)[44], 108[29] \\
107\left(\mathrm{M}^{+}-\mathrm{C}_{3} \mathrm{H}_{5}\right)[22], 105[30], 91\left(\mathrm{C}_{7} \mathrm{H}_{7}^{+}\right) \\
{[22], 77,57[20], 43,41[14] .}\end{array}$ & 5-Isopropenyl-2-methyl-phenol \\
\hline (TB3) & 14.08 & $\begin{array}{l}168(\mathrm{M})^{+}[7], 153\left(\mathrm{M}^{+}-\mathrm{CH}_{3}\right) \quad[13], 150 \\
\left(\mathrm{M}^{+}-\mathrm{H}_{2} \mathrm{O}\right)[47], 139[9], 135\left(\mathrm{M}^{+}-\mathrm{H}_{2} \mathrm{O}-\mathrm{CH}_{3}\right) \\
{[41], 126\left(\mathrm{M}^{+}-\mathrm{C}_{3} \mathrm{H}_{6}\right)[100], 111[42], 104} \\
{[55], 97[37], 91\left(\mathrm{C}_{7} \mathrm{H}_{7}^{+}\right)[25], 83[65], 69} \\
{[30], 55[31], 43[26], 41[31] .}\end{array}$ & $\begin{array}{l}\text { 4-Hydroxy-3-isopropyl-6-methyl-cyclohex-2-enone or } \\
\text { position isomer }\end{array}$ \\
\hline (TB4) & 13.28 & $\begin{array}{l}192(\mathrm{M})^{+}[6], 150 \quad\left(\mathrm{M}^{+}-\mathrm{H}_{2} \mathrm{C}_{2} \mathrm{O}\right)[34], 135 \\
\left(\mathrm{M}^{+}-\mathrm{H}_{2} \mathrm{C}_{2} \mathrm{O}-\mathrm{CH}_{3}\right)[100], 115[10], 105,91 \\
\left(\mathrm{C}_{7} \mathrm{H}_{7}^{+}\right)[15], 77\left(\mathrm{C}_{6} \mathrm{H}_{5}^{+}\right)[7] .\end{array}$ & Thymyl acetate ${ }^{*} \dagger$ \\
\hline (TB5) & 13.88 & $\begin{array}{l}168(\mathrm{M})^{+}[6], 153\left(\mathrm{M}^{+}-\mathrm{CH}_{3}\right)[12], 150 \\
\left(\mathrm{M}^{+}-\mathrm{H}_{2} \mathrm{O}\right)[49], 139[8], 135\left(\mathrm{M}^{+}-\mathrm{H}_{2} \mathrm{O}-\mathrm{CH}_{3}\right) \\
{[31], 126\left(\mathrm{M}^{+}-\mathrm{C}_{3} \mathrm{H}_{6}\right)[100], 111[41], 107} \\
{[24], 97[37], 83[55], 69[32], 55[34], 43} \\
{[43] .}\end{array}$ & $\begin{array}{l}\text { 4-Hydroxy-6-isopropyl-3-methyl-cyclohex-2-enone or } \\
\text { position isomer }\end{array}$ \\
\hline$(T B 6)$ & 13.04 & $\begin{array}{l}182(\mathrm{M})^{+}[7], 140\left(\mathrm{M}^{+}-\mathrm{H}_{2} \mathrm{C}_{2} \mathrm{O}\right)[20], 139 \\
\left(\mathrm{M}^{+}-\mathrm{H}_{2} \mathrm{C}_{2} \mathrm{O}-\mathrm{H}\right)[15], 122[19], 112[25], 111 \\
\left(\mathrm{M}^{+}-\mathrm{H}_{2} \mathrm{C}_{2} \mathrm{O}-\mathrm{C}_{2} \mathrm{H}_{4}-\mathrm{H}\right)[100], 96[39], 83[19] \\
96[39], 83[18] .\end{array}$ & 2-Hydroxymethyl-5-isopropyl-benzene-1,4-diol ${ }^{\star}$ \\
\hline
\end{tabular}

Identified by: ${ }^{*}$, proved with authentic standard and NMR; ${ }^{\dagger}$, mass spectrum identical with literature spectrum; ${ }^{\ddagger}$, structure derived from the interpretation of the mass spectrum. ${ }^{\mathrm{a}}$ Notation indicates the substrate and microorganism used: (C)-C. acutatum, CC; (C)B. theobromae, CB; (T)-C.acutatum, TC; (T)-B. theobromae, TB. (CC1) is the same compound that (TC2), (CB2), (TB2). Similarly, $(C C 2)=(C B 4) ;(C C 5)=(C B 5) ;(C C 6)=(C B 7) ;$ and $(T C 1)=(T B 1)$. 
Thymol and carvacrol: biotransformation and antifungal activity...
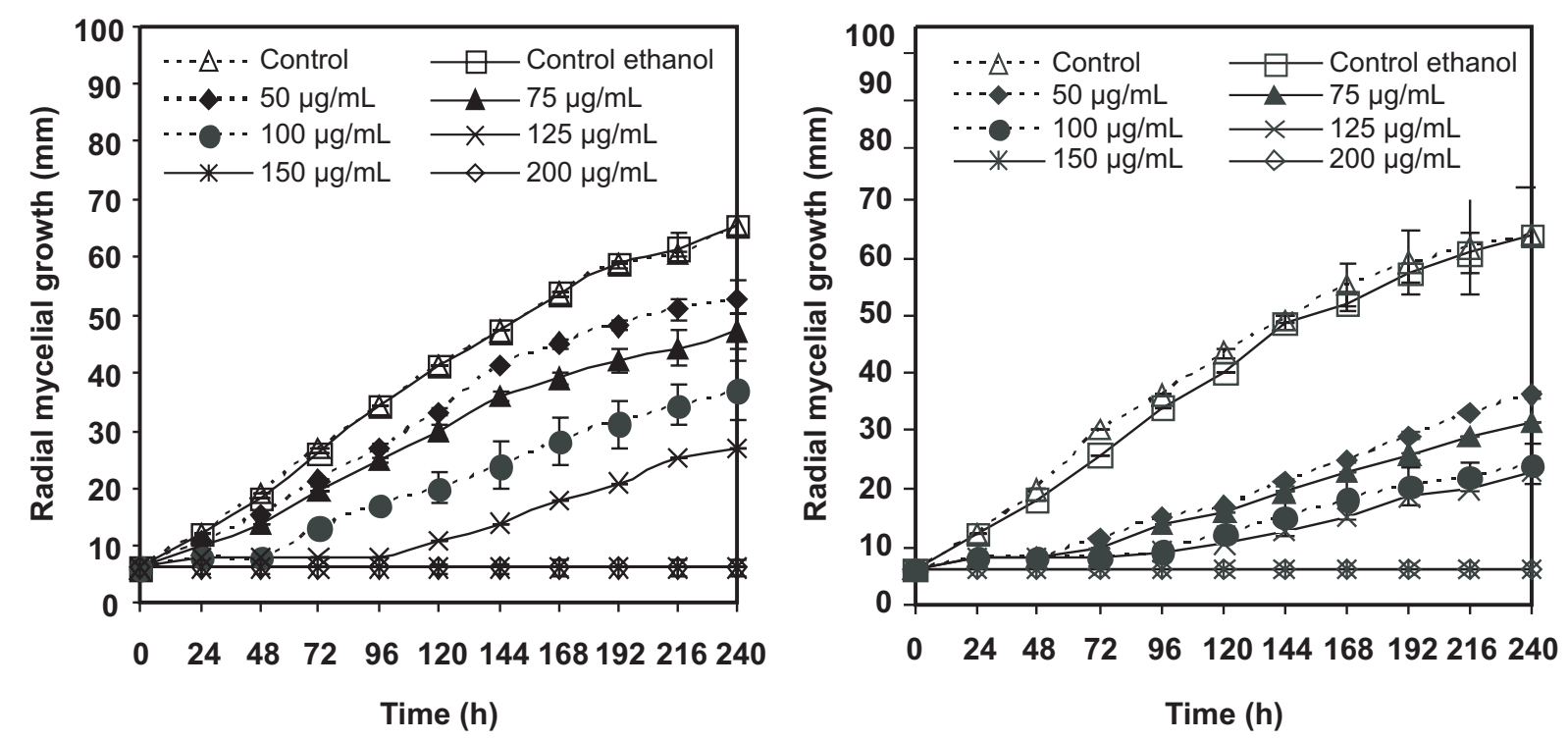

FIGURE 1 - Effect of (C) (left) and (T) (right) on radial mycelial growth of C. acutatum. Results are shown as average values of three replicates of mycelium diameter; $\mathrm{bar}= \pm \mathrm{SD}$.
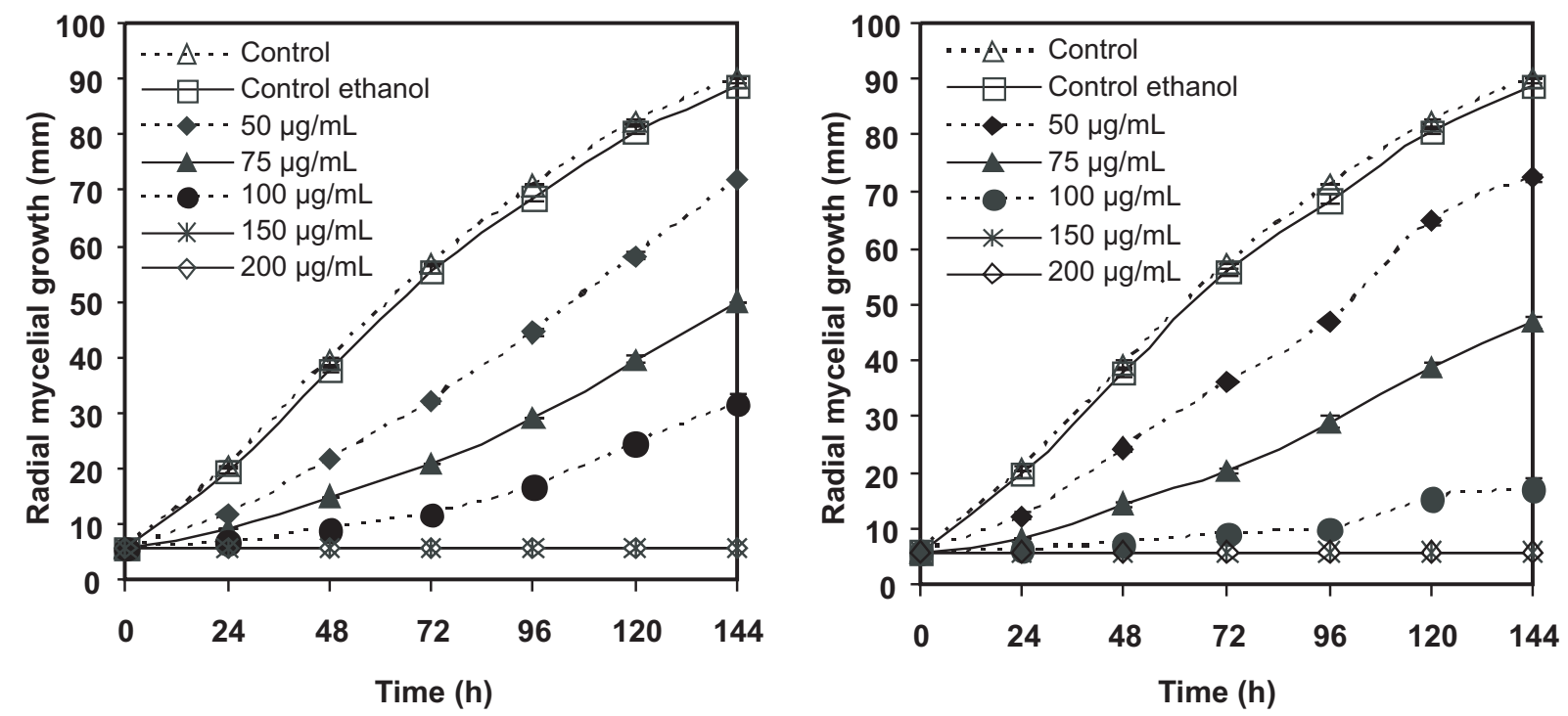

FIGURE 2 - Effect of (C) (left) and (T) (right) on radial mycelial growth of B. theobromae. Results are shown as average values of three replicates of mycelium diameter; bar $= \pm \mathrm{SD}$.

wall enzymes like chitin synthase/chitinase as well as with the $\alpha$ - and $\beta$-glucanases of the fungus (Adams et al., 1996).

Although the difference between (T) and (C) is only in the position of the hydroxyl group, (T) was more active than $(\mathrm{C})$ against $C$. acutatum. Growth inhibition percentages of $C$. acutatum achieved by (T) and (C) at $100 \mu \mathrm{g} / \mathrm{mL}$ for 10 days were from 86.0 (day 1) to 55.0 (day 10), and from 63.0 (day 1) to $30.5 \%$ (day 10), respectively. Different studies indicate that the position of the hydroxyl group is very important in antifungal and insecticidal activity (Kim et al., 2008; Park et al., 2008).
For B. theobromae, only slight differences in the percentage of inhibition among (T) and (C) were found. Inhibition of $B$. theobromae growth by (T) at $100 \mu \mathrm{g} / \mathrm{mL}$ and for 6 days reached values between 97.7 (day 1) and 86.5\% (day 6), whereas for (C) the values were between 93.2 (day 1) and $69.1 \%$ (day 6). As can be seen, growth inhibition percentages of $C$. acutatum and B. theobromae achieved by (T) and (C) at $100 \mu \mathrm{g} / \mathrm{mL}$ decreased with time, a fact which suggests that both fungi possess a detoxification mechanism. Similar behavior occurred when (T) and (C) were evaluated at concentrations below $150 \mu \mathrm{g} / \mathrm{mL}$ (data not shown). 


\section{Metabolic compounds}

A comparison of the TLC profiles and GC chromatograms obtained from biotransformation and the control, showed that C. acutatum transformed (C) into six major metabolites and a small amount of minor compounds not found in the control (data not shown). The structures of these metabolites were determined from the interpretation of spectral data (MS and NMR), and comparison with authentic samples (Table 1).

Two compounds (CC1 and $C C 2$ ) had a molecular formula of $\mathrm{C}_{10} \mathrm{H}_{14} \mathrm{O}_{2}$ based on its mass spectrum, $(\mathrm{M})^{+}=$ $166 \mathrm{amu}$. The molecular ion was 16 mass units higher than that of the parent compound $(\mathrm{C})$, indicating the addition of a hydroxyl group to $(\mathrm{C})$. Metabolite $(C C 1)$ had a fragment ion at $\mathrm{m} / \mathrm{z} 151$ (base peak) attributed to the loss of methyl group. Also, peaks of low intensity appear at $\mathrm{m} / z 123$ and 43, corresponding to loss of isopropyl group and formation of isopropyl cation, respectively. From the spectral data, $(C C 1)$ was elucidated to be 2-methyl-5-isopropylhydroquinone (thymohydroquinone).Unfortunately, theverylowabundance of ( $C C 1)$ from the biotransformation excluded purification, enrichment and further spectroscopic characterization, and the full structural confirmation required the synthesis of this compound. The mass spectrum and retention time for $(C C 1)$ were consistent with those of synthetic thymohydroquinone obtained according to literature (El-Dakhakhny, 1963). It is noteworthy that thymohydroquinone was previously reported to be produced during biotransformation of $(\mathrm{T})$ and $(\mathrm{C})$ by a Pseudomonas strain (Chamberlain \& Dagley, 1968). Similarly, metabolic product (CC2) gave fragment ions at $\mathrm{m} / \mathrm{z} 43$ (base peak) and 151 indicating formation of isopropyl cation and loss of methyl group. Also, $(C C 2)$ gave a peak at $\mathrm{m} / \mathrm{z} 107$ (absent in CC1) corresponding to loss of $\left(\mathrm{CH}_{3}\right)_{2} \mathrm{CO}$ plus the radical hydrogen. This metabolite was tentatively identified as 5-(1-Hydroxy-1-methyl-ethyl)-2methyl-phenol.

Three compounds $(C C 3, C C 4$ and $C C 5)$ presented a molecular formula $\mathrm{C}_{10} \mathrm{H}_{12} \mathrm{O}_{2}$ consistent with the molecular ion, $\mathrm{M}^{+}=164$ amu. Metabolite (CC3) had fragment ions at $\mathrm{m} / \mathrm{z} 149$, 147 , and 121 attributed to the loss of methyl, hydroxyl and isopropyl groups, respectively. From the spectral data, (CC3) was tentatively elucidated to be 2-Isopropenyl-5methyl-benzene-1,4-diol. (CC4) corresponded to methyl ether derivative of carvacrol. Fragments at $\mathrm{m} / \mathrm{z} 149$ $\left(\mathrm{M}^{+}-\mathrm{CH}_{3}\right), 121\left(\mathrm{M}^{+}-\mathrm{C}_{3} \mathrm{H}_{7}\right), 91\left(\mathrm{C}_{7} \mathrm{H}_{7}^{+}\right)$and 77 confirmed this conclusion. Also, compound $\mathrm{CC} 4$ was identified by comparing the retention time of GC and GC-MS with an authentic sample, and NMR data: ${ }^{1} \mathrm{H}$ NMR: $\delta 1.14(\mathrm{~d}$, $6 \mathrm{H}, J=7.0), 2.24$ (s, 3H), 2.85 (sept., 1H, 7.0), 3.90 $(\mathrm{s}, 3 \mathrm{H}), 6.88(\mathrm{~d}, 1 \mathrm{H}, J=2.0), 7.13(\mathrm{dd}, 1 \mathrm{H}, J=7.8$, $2.0), 7.27(\mathrm{~d}, 1 \mathrm{H}, J=7.8)$. Mass spectrum of product (CC5) was characterized primarily by the fragment ions at $m / z 149,136$ and 121 , corresponding to the loss of a methyl group, carbon monoxide, and isopropyl group, respectively. Comparison of the mass spectrum with that reported in the NIST 2002 Mass Spectral Library indicated that (CC5) was thymoquinone. Also, compound CC5 was identified by comparing the retention time of GC and GCMS with an authentic sample, and NMR data: ${ }^{1} \mathrm{H}$ NMR: $\delta$ 1.10-1.30 (d, 6H), 2.24 (s, 3H), 3.10-3.20 (m, 1H), 6.55 (s, $1 \mathrm{H}), 6.64(\mathrm{~s}, 1 \mathrm{H}) .{ }^{13} \mathrm{C}$ NMR: 15.4, 21.4, 26.5, 77.2, 130.4, $133.9,145.5,155.3,190.1,191.6$. Thymoquinone was previously reported to be produced upon biotransformation of (T) by immobilized microalgae for $24 \mathrm{~h}$ (Rasoul-Amini, 2010). The authors found that (T) was hardly converted into thymoquinone and suggested that this low level of transformation may be due to $(\mathrm{T})$ toxicity. The molecular formula of compound (CC6) was shown to be $\mathrm{C}_{12} \mathrm{H}_{16} \mathrm{O}_{2}$ on the basis of its mass spectrum $\left(\mathrm{M}^{+} 192 \mathrm{amu}\right)$. MS analyses gave the fragment ion $(\mathrm{m} / \mathrm{z} 150)$, which corresponded to loss of the neutral molecule of ketene $\left(\mathrm{M}^{+}-\mathrm{CH}_{2}=\mathrm{C}=\mathrm{O}\right)$ and suggests the presence of the acetyl group. The metabolite (CC6) was identified as carvacryl acetate. The structure of (CCO) was confirmed by co-injection with authentic carvacryl acetate and NMR data: ${ }^{1} \mathrm{H}$ NMR: $\delta 1.32(\mathrm{~d}, 6 \mathrm{H}, J$ $=7.0), 2.22(\mathrm{~s}, 3 \mathrm{H}), 2.37(\mathrm{~s}, 3 \mathrm{H}), 2.95$ (sept., $1 \mathrm{H}, J=7.0)$, 6.94 (d, 1H, $J=2.0$ ), 7.10 (dd, 1H, $J=8.0,2.0), 7.23$ (d, $1 \mathrm{H}, J=8.0)$; ${ }^{13} \mathrm{C}$ NMR: $16.2,21.3,24.4,34.0,120.2,124.6$, 127.6, 131.4, 148.5, 149.8, 169.7 .

Using (T) $(80 \mu \mathrm{g} / \mathrm{mL})$ as substrate and C. acutatum as biocatalyst, three major metabolites (TC1, TC2, and TC3), and many minor compounds were detected by GC analysis. The MS spectrum of metabolite (TC1) exhibited a molecular ion at $m / z=166(\mathrm{M})^{+}$and a fragmentation pattern consistent with the loss of methyl group $\left(\mathrm{M}^{+}-15\right.$; base peak), the methyl group plus water $\left(\mathrm{M}^{+}-18-15\right)$, and the acetaldehyde plus the hydrogen radical at $\mathrm{m} / \mathrm{z}=$ 121 amu. As a result, metabolite (TC1) was tentatively identified as 2-(1-Hydroxy-1-methyl-ethyl)-5-methylphenol. Otherwise, compound (TC2) showed a retention time $(R t)$ and mass spectrum indistinguishable from that obtained for an authentic sample of thymohidroquinone. In addition, metabolite (TC3) was identified by comparing the retention time of GC and GC-MS with an authentic sample of thymyl methyl ether, and NMR data: ${ }^{1} \mathrm{H}$ NMR: $\delta: 1.22(\mathrm{~d}, 6 \mathrm{H}, J=7.0), 2.33(\mathrm{~s}, 3 \mathrm{H}), 3.37$ (sept., $1 \mathrm{H}, J=$ $7.0), 3.80(\mathrm{~s}, 3 \mathrm{H}), 6.79(\mathrm{~d}, 1 \mathrm{H}, J=8.0), 6.92(\mathrm{dd}, 1 \mathrm{H}, J=$ 8.0, 2.0), 7.05 (d, $J=8.0) .{ }^{13} \mathrm{C}$ NMR: $\delta ~ 21.3,23.5,27.6$, $56.3,112.3,125.9,126.6,137.0,137.5,158.4$. Some of these metabolites detected for $C$. acutatum were also found when an incubation of $(\mathrm{C})$ and $(\mathrm{T})$ using $B$. theobromae was carried out (Table 1). In fact, retention times (Rts) and mass spectra of $(C C 1)=(T C 2),(C C 2),(C C 5),(C C 6)$, and $(T C 1)$ were similar to those obtained for $(C B 2)=(T B 2),(C B 4)$, $(C B 5),(C B 7)$, and $(T B 1)$, respectively.

Likewise, microbial transformation of $(C)$ by $B$. theobromae afforded seven major metabolites not detected in a fungal culture medium lacking the substrate. Metabolic products $(C B 2),(C B 4),(C B 5)$ and $(C B 7)$ showed retention times and mass spectra (Table 1) identical to those observed for the thymohydroquinone, 5-(1-Hydroxy-1-methyl-ethyl)2-methyl-phenol, thymoquinone, and carvacryl acetate, 
Thymol and carvacrol: biotransformation and antifungal activity...

respectively. In addition, the structure of $(C B 1),(C B 3)$, and $(C B 6)$ was derived from their EI mass spectra. The fragmentation pattern of $(C B 1)$, as listed in the experimental section, was in good agreement with the proposed structure. Metabolite $(C B 1)$ had a molecular formula $\mathrm{C}_{10} \mathrm{H}_{14} \mathrm{O}_{2}$ consistent with the molecular ion, $\mathrm{M}^{+}=166 \mathrm{amu}$. In addition, this compound showed fragment ions to $\mathrm{m} / \mathrm{z}=$ 135 and 105 consistent with the loss of $\mathrm{H}_{2} \mathrm{CO}$ and hydrogen radica, 1 and with water, ethylene and methyl radical. Thus, (CB1) was suggested to be 5-(2-hydroxy-1-methyl-ethyl)-2methyl-phenol. Metabolite (CB3) had a molecular formula $\left(\mathrm{C}_{10} \mathrm{H}_{14} \mathrm{O}_{2} ; \mathrm{M}^{+}=166\right)$ and fragment ions at $m / z 148\left(\mathrm{M}^{+-18}\right)$, $133\left(\mathrm{M}^{+}-18-15\right)$, and $105\left(\mathrm{M}^{+}-18-28-15\right)$ attributed to the loss of water, water + methyl radical, and water + ethylene + methyl radical, respectively. From the spectral data, (CB3) was tentatively elucidated to be 2-hydroxymethyl5-isopropyl-phenol. Metabolic compound (CB6) had a molecular formula of $\mathrm{C}_{10} \mathrm{H}_{12} \mathrm{O}$ based on its mass spectrum, $(\mathrm{M})^{+}=148 \mathrm{amu}$. The molecular ion was 2 mass units $(2 \mathrm{H})$ lower than that of parent compound $(\mathrm{C})$, indicating the elimination of hydrogen from (C). Metabolite $(C B O)$ had fragment ions at $\mathrm{m} / \mathrm{z} 133$ and 107 attributed, in that order, to the loss of methyl and isopropylene groups. From the spectral data, $(C B 6)$ was elucidated to be 5-Isopropenyl-2methyl-phenol.

Upon incubation of $(\mathrm{T})$ with $B$. theobromae, six major metabolites were detected by GC-MS analysis. The structures of (TB3), (TB5), and (TBO) were derived from their EI mass spectra. It should be emphasized that the data only tentatively suggest the identity of these metabolites. The molecular formula of compounds (TB3) and (TB5) was shown to be $\mathrm{C}_{10} \mathrm{H}_{16} \mathrm{O}_{2}$ on the basis of its mass spectrum $\left(\mathrm{M}^{+}\right.$ $=168 \mathrm{amu})$. These metabolic products gave fragment ions at $m / z 153,150$, and 135 indicating the loss of methyl group, water, and both, respectively. Also, there was a prominent peak at $m / z=126$ (base peak), corresponding to a ring fission fragment. Although these data do not allow a definitive identification, they suggest a hydroxy-cyclohexenone substituted-like structure for metabolites (TB3) and (TB5). Furthermore, metabolite (TB6) had a molecular formula $\mathrm{C}_{10} \mathrm{H}_{14} \mathrm{O}_{3}$ consistent with the molecular ion, $\mathrm{M}=182 \mathrm{amu}$. The mass spectrum showed fragment ions at $\mathrm{m} / \mathrm{z} 140,139,111$ (base peak), and 96 among others, corresponding to the loss of the ketene $\left(\mathrm{M}^{+}-\mathrm{CH}_{2}=\mathrm{C}=\mathrm{O}\right)$, ketene plus hydrogen radical, ketene + ethylene + hydrogen radical, and $\mathrm{M}^{+}-\mathrm{C}_{5} \mathrm{H}_{10} \mathrm{O}$, respectively. (TB6) was tentatively elucidated to be 2-Hydroxymethyl-5isopropyl-benzene-1,4-diol.

Finally, (TB4) was identified by comparing the retention times of GC-MS with those of authentic samples, and NMR data. NMR data for $(T B 4)$ were: ${ }^{1} \mathrm{H}$ NMR: $\delta$ $1.22(\mathrm{~d}, 6 \mathrm{H}, J=7.0), 2.38$ (s, 3H), 2.39 (s, 3H), 3.05 (sept., $1 \mathrm{H}, J=7.0), 6.89(\mathrm{~d}, 1 \mathrm{H}, J=2.0), 7.11(\mathrm{dd}, 1 \mathrm{H}, \quad J=8.0$, 2.0), 7.29 (d, $1 \mathrm{H}, J=8.0) ;{ }^{13} \mathrm{C}$ NMR: 21.2, 21.3, 23.5, 27.6, $123.2,126.9,127.6,137.1,137.5,148.4,170.2$. Also, the mass spectrum of (TB4) was consistent with that reported in the NIST 2002 Mass Spectral Library for thymyl acetate.

\section{Time course experiment}

The time course of relative concentration changes of $(\mathrm{T})$ and $(\mathrm{C})$ and metabolites is represented in Figures 3A-D. The starting substrate $(\mathrm{C})$ was consumed slowly by both fungi. The fungus $B$. theobromae only transformed about $50 \%$ of $(\mathrm{C})$ after 14 days, being mainly converted to $(C B 1)$ and $(C B 4)$. However, the relative abundance of both metabolites was always lower than $20 \%$. As is shown in Figure $3 \mathrm{~A}$, the other metabolites reached very low concentrations.

Furthermore, C. acutatum metabolized (C) more quickly than $B$. theobromae. Interestingly, some metabolites produced from (C) by $C$. acutatum were not detected in a fungal culture of $B$. theobromae incubated with the same substrate. According to Figure 3B, the substrate (C) was mainly transformed by $C$. acutatum to $(C C 4)(\sim 12 \%)$ and about $55 \%$ was consumed in 14 days. These results suggest that under the conditions used, (C) can be only slowly detoxified by the plant pathogenic fungi. Otherwise, (C) was metabolized at a faster rate than (T) by $C$. acutatum (Figures 3B and 3D).

As can be seen from Figure $3 \mathrm{C}$, the substrate $(\mathrm{T})$ was only transformed by about $55 \%$ after 14 days, using $B$. theobromae as biocatalyst. The major metabolic product (TB1) reached a relative abundance of $\sim 20 \%$ after 11 days. In addition, metabolites (TB2), (TB3), (TB4), (TB5), and (TB6) presented relative abundances below $10 \%$ during the time of analysis. It seems noteworthy that (T) was consumed by $B$. theobromae to a greater extent than $C$. acutatum. In fact, analysis of extracts obtained from fungal cultures of C. acutatum incubated with (T) showed it to be weakly metabolized $(<10 \%)$ (Figure 3D). In addition, some metabolites previously detected on incubation of $(\mathrm{T})$ with $B$. theobromae were absent in the biotransformation using C. acutatum.

The marked difference between the metabolism of (C) and (T) by C. acutatum may reflect the higher toxicity (antifungal activity) of (T) against this pathogenic fungus. In the same way, small differences between the metabolisms of both compounds by $B$. theobromae are consistent with the observed similarities in the antifungal activity against this fungus. Based on the structures of the metabolites, metabolic pathways for the biotransformation of $(\mathrm{C})$ and $(\mathrm{T})$ by $C$. acutatum and B. theobromae were proposed (Figure 4).

Overall, it becomes apparent that aromatic and aliphatic hydroxylation, and the methylation and acetylation of hydroxyl group over aromatic ring, represents the main metabolic pathway from (C) and (T) by both phytopathogenic fungi. These transformations may be the result of a process of detoxification of both phenolic compounds by $C$. acutatum and B. theobromae. Recent studies have demonstrated the necessity of the phenolic hydroxyl group of (C) for antimicrobial activity (Ultee et al., 2002). The elimination of the hydroxyl group by replacing it with the methyl ether or methyl ester group affects the hydrophobicity of the molecule and the size of the ring 

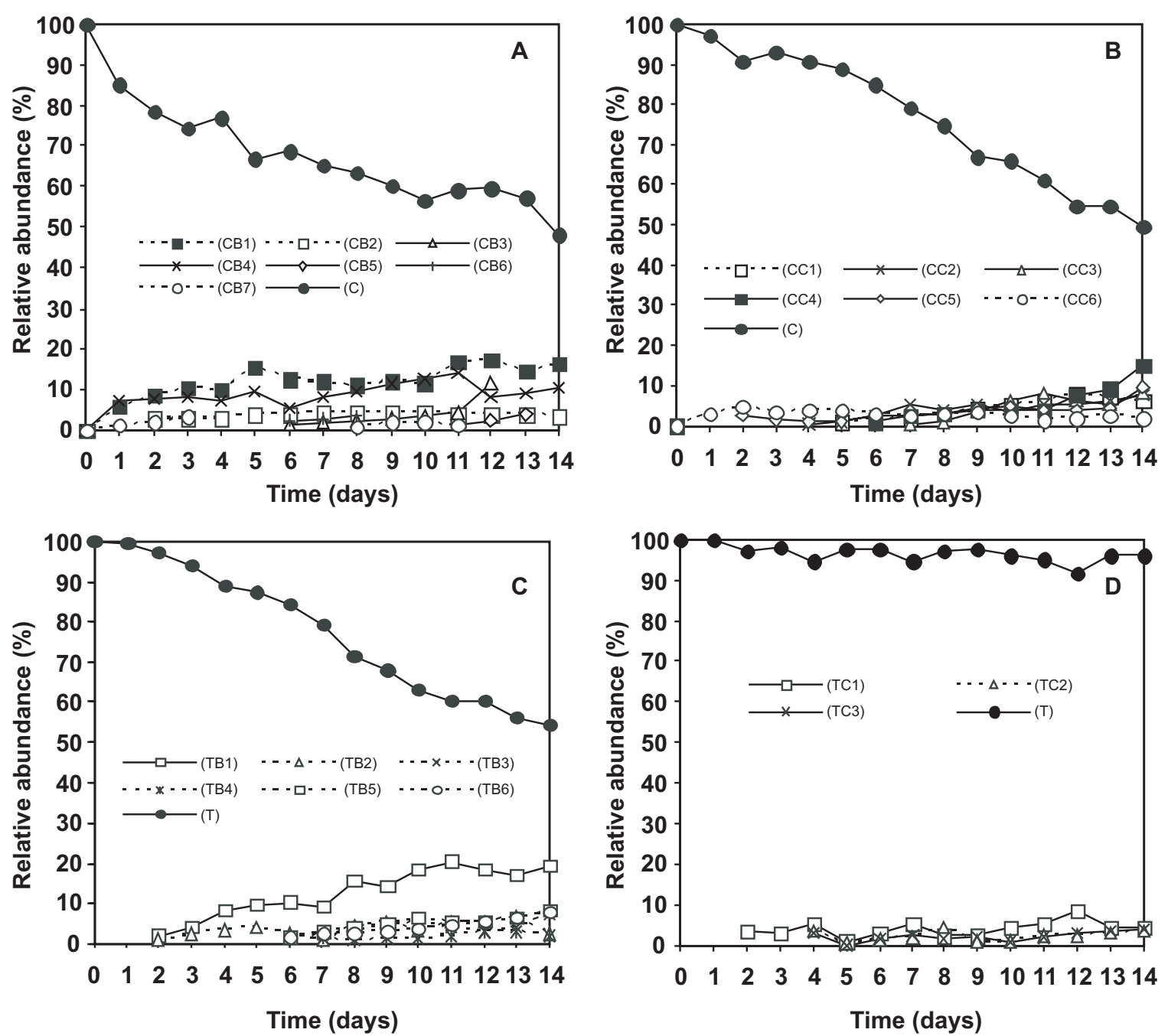

FIGURE 3 - Time course for the microbial transformation of: (C) by B. theobromae (3a) and C. acutatum (3b); and (T) by $B$. theobromae (3c) and $C$. acutatum (3d). (CC1) is the same compound that (TC2), (CB2), (TB2). Similarly, $(C C 2)=$ $(C B 4) ;(C C 5)=(C B 5) ;(C C 6)=(C B 7) ;$ and $(T C 1)=(T B 1)$.

substituent, both of which may have a major influence on specific interactions with microbial cells. Veldhuizen et al. (2006) found that carvacrol methyl ether, containing a methyl ether group instead of a hydroxyl group, did not inhibit the growth of $B$. cereus at the concentrations tested (0 to $10 \mathrm{mM}$ ), whereas no growth was observed with (C) at concentrations of $0.75 \mathrm{mM}$ and above. Furthermore, (TC3), $(T B 4)$, and $(C C 6)=(C B 7)$ do not have the ability to release a proton and behave as a proton exchanger.

In addition, the aliphatic side chains have a direct influence on the antimicrobial activity of (C) and (T), as has been described by several researchers (Ultee et al., 2002; Veldhuizen et al., 2006). They have observed that the removal of ring substituents from (C) (using 3isopropylphenol and $o$-cresol) leads to a reduction in antimicrobial activity. Therefore, the hydroxylation of the aliphatic chains of $(\mathrm{C})$ and $(\mathrm{T})$ may be a mechanism used by $C$. acutatum and $B$. theobromae to reduce the antifungal activity. These microbial transformations can reduce the hydrophobic features of these molecules, which may affect the initial interaction with the membrane. Consequently, we suggest that these hydroxylation reactions emerge as potential metabolic targets to control $C$. acutatum and $B$. theobromae. Another important structural feature associated with the antimicrobial activity of $(\mathrm{C})$ and $(\mathrm{T})$ is the presence of a system of delocalized electrons. It was described earlier that the hydroxyl group bound to a benzenic ring is important for the activities of some antimicrobial compounds (Ultee et al., 2002; Veldhuizen et al., 2006; Xu et al., 2008). This feature allows compounds to destabilize the cytoplasmic membrane and act as a proton exchanger, reducing the $\mathrm{pH}$ gradient across the membrane. Hence, we suggested that the formation of $(C C 5)=(C B 5),(T B 5)$, and (TB3) as previous intermediaries reflects the need of $C$. acutatum and $B$. theobromae to reduce the toxicity of $(C)$ and $(\mathrm{T})$ by eliminating the system of delocalized electrons. 
Thymol and carvacrol: biotransformation and antifungal activity...

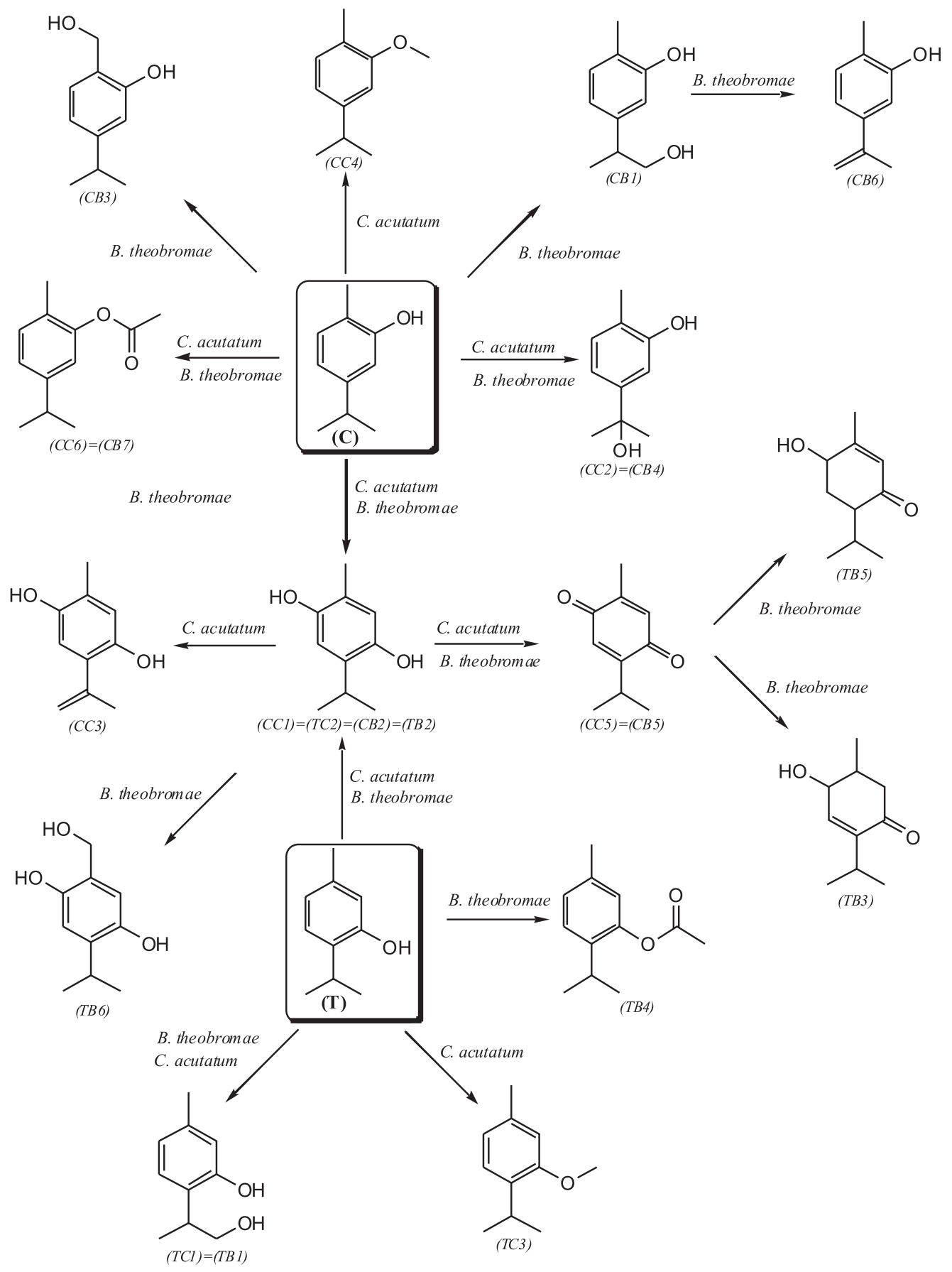

FIGURE 4 - Possible metabolic pathways of (C) and (T) by C. acutatum and B. theobromae

We are currently evaluating the antifungal effect of the obtained metabolic compounds, and some synthetic derivatives of (T) and (C), against $C$. acutatum and $B$. theobromae. Synthetic derivatives present modifications in the aliphatic chains and benzenic ring of (T) and (C), in the same positions that were hydroxylated according to the metabolic studies.

Arylpropanoids, specifically thymol and carvacrol, which are strongly antifungal against the phytopathogenic fungi $C$. acutatum and $B$. theobromae, are mainly metabolized via aromatic and aliphatic hydroxylation, and the methylation and acetylation of hydroxyl group over the aromatic ring. Antifungal activity of thymol was slightly higher than that observed for carvacrol against $C$. acutatum.

In conclusion, the arylpropanoids thymol and carvacrol, which were highly active against the phytopathogenic fungi $C$. acutatum and $B$. theobromae, 
were mainly metabolized via aromatic and aliphatic hydroxylation, and through methylation and acetylation of hydroxyl group. These transformations affect the structural features of thymol and carvacrol associated with their antimicrobial activity and mode of action. Overall, the antifungal activity of thymol was higher than that observed for carvacrol against $C$. acutatum. Consequently, compared to the transformation of carvacrol, the metabolism of thymol by $C$. acutatum was a slower process. Similarly, the small differences in the metabolism of both compounds by $B$. theobromae were consistent with the observed similarities in the antifungal activity against this fungus. High antifungal activity coupled with a low level of microbial transformation makes thymol and carvacrol promising candidates to control C. acutatum and B. theobromae.

\section{ACKNOWLEDGEMENTS}

The authors gratefully acknowledge the financial support of the Vicerrectoría de Investigación, Universidad Nacional de Colombia.

\section{REFERENCES}

Adams S, Kunz B, Weidenbörner M (1996) Mycelial deformations of Cladosporium herbarum due to the application of Eugenol and Carvacrol. Journal of Essential Oil Research 8:535-540.

Afanador-Kafuri L, Minz D, Maymon M, Freeman S (2003) Characterization of Colletotrichum isolates from tamarillo, pasiflora and mango in Colombia and identification of a unique species from genus. Phytopathology 93:579-587.

Alzate DA, Mier GI, Afanador L, Durango DL, García CM (2009) Evaluación de la fitotoxicidad y la actividad antifúngica contra Colletotrichum acutatum de los aceites esenciales de tomillo (Thymus vulgaris), limoncillo (Cymbopogon citratus), y sus componentes mayoritarios. Vitae 16:116-125.

Chamberlain EM, Dagley S (1968) The metabolism of thymol by a Pseudomonas. Biochemical Journal 110:755-763.

Cristani M, D’Arrigo M, Mandalari G, Castelli F, Sarpietro MG, Micieli D., Venuti V, Bisignano G, Saija A, Trombetta D (2007) Interaction of four monoterpenes contained in essential oils with model membranes: implications for their antibacterial activity. Journal of Agricultural and Food Chemistry 55:6300-6308.

Daoubi M, Hernández-Galán R, Benharref A, Collado IG (2005) Screening study of lead compounds for natural product-based fungicides: antifungal activity and biotransformation of $6 \alpha$, $7 \alpha$-Dihydroxy- $\beta$-himachalene by Botrytis cinerea. Journal of Agricultural and Food Chemistry 53:6673-6677.

El-Dakhakhny M (1963) Studies on the chemical constitution of Egiptian Nigella sativa L. seeds II. The essential oil. Planta Medica 11:465-470.

Falcone PM, Speranza B, Del Nobile MA, Corbo MR, Sinigaglia M (2005) A study on the antimicrobial activity of thymol intended as a natural preservative. Journal of Food Protection 68:16641670 .
Grover RK, Moore JD (1962) Toximetric studies of fungicides against brown rot organism. Sclerotina fruticola. Phytopathology 52:876-880.

Holley RA, Patel D (2005) Improvement in shelf-life and safety of perishable foods by plant essential oils and smoke antimicrobials. Review Food Microbiology 22:273-292.

Kim J, Lee YS, Lee SG, Shin SC, Park IK (2008) Fumigant antifungal activity of plant essential oils and components from West Indian bay (Pimenta racemosa) and thyme (Thymus vulgaris) oils against two phytopathogenic fungi. Flavour and Fragrance Journal 23:272-277.

Knobloch K, Pauli A, Iberl B, Weis N, Weigand H (1988) Mode of action of essential oil components on whole cells and fungi in plate tests. In: Schreier P (Ed.) Bioflavor '87. Berlin, New York. Walter de Gruyter Verlag. pp. 287-299.

Martínez EP, Hío JC, Osorio JA, Torres MF (2009) Identification of Colletotrichum species causing anthracnose on Tahiti lime, tree tomato and mango. Agronomía Colombiana 27:211-218.

Mathela CS, Singh KK, Gupta VK (2010) Synthesis and In Vitro antibacterial activity of thymol and carvacrol derivatives. Acta Poloniae Pharmaceutica-Drug Research 67:375-380.

Ormancey X, Sisalli S, Coutiere P (2001) Formulation of essential oils in functional perfumery. Parfums, Cosmetiques, Actualites 157:30-40.

Park IK, Kim JN, Lee YS, Lee SG, Ahn YJ, Shin SC (2008) Toxicity of plant essential oils and their components against Lycoriella ingenua (Diptera: Sciaridae). Journal of Economic Entomology 101:139-144.

Plotto A, Roberts DD, Roberts RG (2003) Evaluation of plant essential oils as natural postharvest disease control of tomato (Lycopersicon esculentum). Acta Horticulturae 628:737-745.

Rasoul-Amini S, Fotooh-Abadi E, Ghasemi Y (2010) Biotransformation of monoterpenes by immobilized microalgae. Journal of Applied Phycology 22:1-7.

Smith MB, March J (2007) March's Advanced Organic Chemistry: Reactions, mechanisms, and structure. 6th ed. Hoboken NJ. John Wiley \& Sons, Inc.

Sokovic M, Tzakou O, Pitarakoli D, Couladis M (2002) Antifungal activities of selected aromatic plants growing wild in Greece. Molecular Nutrition and Food Research 46:317-320.

Soylu S, Yigitbas H, Soylu EM, Kurt S (2007) Antifungal effects of essential oils from oregano and fennel on Sclerotinia sclerotiorum. Journal of Applied Microbiology 103:1021-1030.

Tripathi P, Dubey NK (2004) Exploitation of natural products as an alternative strategy to control postharvest fungal rotting of fruit and vegetables. Postharvest Biology and Technology 32:235-245.

Tripathi P, Shukla AK (2007) Emerging non-conventional technologies for control of post harvest diseases of Perishables. Fresh Produce 1:111-120.

Tsao R, Zhou T (2000) Antifungal activity of monoterpenoids against postharvest pathogens Botrytis cinerea and Monilinia fructicola. Journal of Essential Oil Research 12:113-121.

Ultee A, Bennik MH, Moezelaar R (2002) The phenolic hydroxyl group of carvacrol is essential for action against the foodborne pathogen Bacillus cereus. Applied and Environmental Microbiology 68:1561-1568. 
Ultee A, Kets EPW, Alberda M, Hoekstra FA, Smid EJ (2000) Adaptation of the food-borne pathogen Bacillus cereus to carvacrol. Archives of Microbiology 174:233-238.

Valero D, Valverde JM, Martinez-Romero D, Guillen F, Castillo S, Serrano M (2006) The combination of modified atmosphere packaging with eugenol or thymol to maintain quality, safety and functional properties of table grapes. Postharvest Biology and Technology 41:317-327.

Vázquez BI, Fente C, Franco CM, Vázquez MJ, Cepeda A (2001) Inhibitory effects of eugenol and thymol on Penicillium citrinum strains in culture media and cheese. International Journal of Food Microbiology 67:157-163.

Veldhuizen EJA, Tjeerdsma-Van Bokhoven JLM, Zweijtzer C, Burt SA, Haagsman HP (2006) Structural requirements for the antimicrobial activity of carvacrol. Journal of Agricultural and Food Chemistry 54:1874-1879.

Xu J, Zhou F, Ji BP, Pei RS, Xu N (2008) The antibacterial mechanism of carvacrol and thymol against Escherichia coli. Letters in Applied Microbiology 47:174-179.

TPP 226 - Received 10 December 2010 - Accepted 15 March 2011 Section Editor: Marciel J. Stadnik 